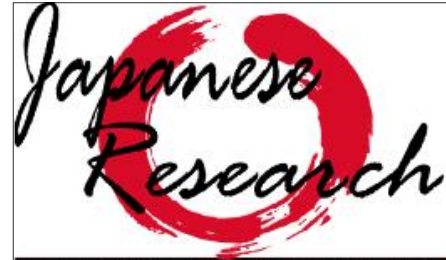

on Linguistics, Literature and Culture
Japanese Research on Linguistics, Literature, and Culture

Vol. 1 No. 2 May 2019, Hal. 154-166

ISSN online: $2655-4836$

http://publikasi.dinus.ac.id/index.php/jrllc/article/view/2501/1601

DOI : 10.33633/ir.v1i2.2501

Published by Universitas Dian Nuswantoro, Semarang

\title{
Analisis Semiotika Puisi Yogorecchimatta Kanashimini Karya Nakahara Chuya
}

\author{
Budi Santoso, Tri Mulyani Wahyuningsih \\ Universitas Dian Nuswantoro \\ budi.santoso@dsn.dinus.ac.id
}

Article History: Submitted date 2019-05-16 ; Accepted date 2019-05-25; Published date 2019-06-01

\begin{abstract}
This article discusses the semiotic analysis of the Yogorecchimatta kanashimini poem by Nakahara Chuya. The data source is the poem which is entitled Yogorecchimatta kanashimini. The approach used in this research is the Riffatere's poetry semiotics with the concern in the analysis of heuistic and hermeneutic reading; analysis of unsustainable expressions; analysis of matrices, model and variants. The analysis result of heuristic and hermeneutic readings indicate that the poetry of Yogorecchimatta kanashimini poem describes the condition of poet's soul. He was afflicted with sadness that made him desperate, helpless and haunted by the fear. Indirect expression occurs through meaning substitution in form of metaphorical use, deviation meaning through ambiguity, and creation of meaning through asonance and repetition of lines. The deep sadness felt by the poet became the poetry matrix, while this soiled sorrow became the poetry model. There are three variants. Those are sorrow makes the poet wander in splash of snow, sorrow makes the poet despair, and sorrow makes the poet helpless.
\end{abstract}

Keywords: Semiotics, Poetry, Riffatere, Nakahara Chuya

\begin{abstract}
Abstrak
Makalah ini membahas analisis semiotika puisi Yogorecchimatta kanashimini karya Nakahara Chuya. Sebagai sumber data adalah puisi Yogorecchimatta kanashimini. Ancangan penelitian menggunakan semiotika puisi Riffatere dengan fokus penelitian pada analisis pembacaan heuistik dan hermeneutik, analisis ketidaklangsungan ekspresi, serta analisis matrik, model dan varian. Hasil analisis pembacaan heuristik dan hermeneutik menunjukkan bahwa puisi menggambarkan kondisi jiwa penyair yang dilanda sedih sehingga membuatnya putus asa dan tak berdaya serta dihantui rasa takut. Ketidaklangsungan ekspresi terjadi melalui penggantian arti yang berupa penggunaan metaforo, penyimpangan arti melalui ambiguitas, serta penciptaan arti melalui asonansi dan pengulangan baris. Kesedihan mendalam yang dirasakan penyair menjadi matrik puisi, sedangkan kesedihan yang kotor ini menjadi model puisi. Terdapat tiga varian yaitu kesedihan membuat penyair hanyut dalam guyuran butiran salju, kesedihan membuat penyair putus asa, dan kesedihan membuat penyair tak berdaya.
\end{abstract}


Kata Kunci: Semiotika, Puisi, Riffatere, Nakahara Chuya

\section{Pendahuluan}

Puisi merupakan sebuah ungkapan dari pengarang dalam menyampaikan sesuatu. Apa yang ingin disampaikan pengarang sulit dimaknai hanya dengan sekali membaca. Hal ini dikarenakan pengarang menyajikan puisi dengan cara yang berbeda dari karya sastra lainnya. Sayuti (2002:18) menyatakan bahwa puisi adalah sebuah struktur yang terdiri atas berbagai unsur. Unsur-unsur yang membentuk puisi berupa kata-kata, bentuk, pola, rima, ritma, ide, makna atau gagasan yang ingin disampaikan penyair kepada pembaca, pendengar, melalui teknik dan aspek-aspek tertentu. Puisi mengekspresikan pemikiran yang membangkitkan perasaan dan merangsang imajinasi pancaindra melalui jalinan unsurunsur puisi yang erat (Prahasita, 2016:125).

Penggunaan bahasa dalam suatu puisi jelas berbeda dengan pemakaian bahasa pada umumya. Puisi dibust sedemikian rupa sehingga bahasa puisi seolah-olah memiliki semacam "tata bahasa" khusus yang terkadang sangat menyimpang jika dilihat dari segi bahasa normatif (Sayuti, 2008: 23). Dengan demikian, dapat dikatakan bahwa hal yang membedakan bahasa puisi dengan bahasa pada umumnya adalah bahwa puisi ditulis dengan bahasa tidak langsung sehingga untuk memahami puisi dibutuhkan suatu analisis tersendiri agar dapat dipahami maknanya. Penggunaan bahasa dalam puisi lebih berfungsi untuk menggambarkan, membentuk, dan mengekspresikan gagasan, perasaan, pandangan, dan sikap penyairnya. Berkaitan dengan ketidaklangsungan bahasa puisi, Riffatere (1978:1) dengan jelas menyatakan bahwa puisi menyampaikan sesuatu secara tidak langsung. Ketidaklangsungan ekspresi yang terdapat dalam puisi merupakan daya tarik puisi dibandingkan karya sastra lain. Ketidaklangsungan ini dibuat agar tercapai tenaga puisi hingga terasa apa yang diungkapkan. Selain itu juga, ketidaklangsungan juga menimbulkan ketegangan puitis dan memperjelas maksud puisi (Pradopo, 1997: 71).

Makalah ini mencoba mengkaji dan menganalis gagasan yang ingin disampaikan oleh penyair dalam puisi 污れつちまつた悲しみに “Kesedihan yang kotor ini” karya Nakahara Chuya. Analisis puisi menggunakan ancangan semitika puisi dari Riffaterre.karena mengarah 
langsung kepada pemaknaan puisi sehingga dapat dihasilkan pemahaman yang jelas tentang apa yang ingin disampaikan penyair.

\subsection{Semiotika Puisi}

Semiotik merupakan ilmu yang mempelajari tentang tanda dan hubungan antara tanda-tanda tersebut. Secara sistematik, semiotik menjelaskan esensi, ciri-ciri, dan bentuk suatu tanda, serta proses signifikasi yang menyertainya (Alex Sobur, 2004: 16). Sebagai salah satu bentuk karya sastra, puisi merupakan suatu susunan tanda yang berupa ungkapan atau tuturan dalam bentuk bahasa yang berbeda dengan tuturan bahsa sehari-hari. Hal ini diungkapkan Riffaterre (dalam Ratih, 2016: 5) dengan menyatakan bahwa aktivitas bahasa yang berbeda dengan pemakaian bahasa pada umumnya. Dalam hal ini, puisi mengungkapkan sesuatu secara tidak langsung dan menyembunyikannya dalam suatu tanda. Ketidaklangsungan inilah yang menjadi ciri utama dan daya tarik puisi jika dibandingkan dengan karya sastra lainnya. Untuk dapat menghasilkan makna puisi terdapat empat hal yang harus diperhatikan yaitu pembacaan heuristik dan hermeneutik, ketidaklangsungan ekspresi, matriks, model, dan varian, dan hipogram atau hubungan intertekstual. Keempat hal tersebut dapat dijelaskan sebagai berikut:

1) Pembacaan Heuristik dan Pembacaan Hermeneutik

Pembacaan heuristik merupakan proses memparagrafkan atau menarasikan suatu puisi atau sering disebut sebagai parafrase. Dalam hal ini, puisi dibaca berdasarkan konvensi bahasa atau sistem bahasa sesuai dengan kedudukan bahasa sebagai sistem semiotik tingkat pertama (Pradopo, 2010: 295). Dengan kata lain, puisi dibaca sesuai dengan makna literal kata-kata yang menyusunnya. Pembacaan hermeneutik, adalah pembacaan ulang dari awal sampai akhir dengan penafsiran dan pemberian makna berdasarkan konvensi sastra atau puisi itu sendiri (Pradopo, 2010: 297). Pembacaan hermeneutik membaca puisi melalui tanda bahasa dalam kedudukannya sebagai sistem semiotik tingkat kedua. Di sini akan dicari makna dari gagasan tidak langsung yang membentuk puisi.

2) Ketidaklangsungan Ekspresi

Menurut Riffaterre (1978:2) ketidaklangsungan ekspresi disebabkan oleh tiga hal, yakni penggantian arti, penyimpangan arti, dan penciptaan arti. 


\section{3) Penggantian Arti}

Penggantian arti disebabkan oleh penggunaan bahasa kiasan, seperti simile, metafora, personifikasi, metonimi, sinekdoki, dan lain-lain. Dalam hal ini suatu kata atau tanda memiliki arti lain (tidak literal). Bahasa kias berfungsi sebagai alat untuk menciptakan efek puitis..

\section{4) Penyimpangan Arti}

Menurut Riffaterre (dalam Pradopo, 2010: 213) penyimpangan arti terjadi bila terdapat ambiguitas, kontradiksi maupun nonsense. Adanya ambiguitas akan memberi kesempatan kepada pembaca memaknai puisi di luar makna literalnya. Kontradiksi merupakan salah satu cara menyampaikan maksud puisi secara berlawanan atau berkebalikan. Nonsense merupakan bentuk kata-kata yang secara linguistik tidak mempunyai arti sebab tidak terdapat dalam kosakata. Munculnya nonsense diakibatkan oleh permainan bunyi itu sendiri dalam puisi.

5) Penciptaan arti.

Riffaterre (dalam Pradopo, 2010: 220) menjelaskan bahwa penciptaan arti terjadi bila ruang teks (spasi teks) yang berlaku sebagai prinsip pengorganisasian untuk tanda keluar dari hal-hal ketatabahasaan dan secara linguistik tidak ada artinya Penciptaan arti dapat terlihat dalam bentuk simitri (keseimbangan), rima/ritme, enjambemen (perloncatan kesatuan sintaksis), serta persamaan posisi (homologues).

6) Matriks, Model, Varian

Pradopo (2010: 299), menjelaskan bahwa untuk mengupas puisi agar dapat mudah dipahami, haruslah ditemukan matriks atau kata-kata kuncinya. Kata-kata kunci adalah kata yang menjadi kunci penafsiran puisi. Matriks bersifat hipotesis dan hanya merupakan aktualisasi gramatikal dan leksikal sebuah struktur puisi. Matriks bisa dilambangkan dalam satu kata, yang mungkin tidak ada dalam teks. Lebih lanjut, matrik diaktualisasikan dalam bentuk model, sesuatu yang dapat dilihat dalam teks puisi. Penjabaran dari model berupa varian yang bisa ditemukan dalam setiap bait puisi.

7) Hipogram

Riffaterre (dalam Pradopo, 2010: 300) mengemukakan hipogram adalah teks yang menjadi latar penciptaan teks lain atau sajak yang menjadi latar penciptaan sajak lainnya. 
Hipogram merupakan keterkaitan teks dengan teks yang sudah ada sebelumnya (Riffaterre, 1978: 23).

\subsection{Metode Penelitian}

Penelitian ini merupakaan penelitian yang menggunakan paradigma kualitatif deskriptif. Dalam hal ini hasil penelitian ditulis dan dideskripsikan dengan kata-kata. Sebagai ancangan penelitian digunakan ancangan semiotika puisi dari Michael Riffatere. Fokus diberikan pada analisi terhadap pembacaan heuristik dan hermeneutik, analisis ketidaklangsungan ekspresi, serta analisis matriks, model, dan varian. Sebagai sumber data digunakan puisi i 污れつちまつた悲しみに Yogorecchimatta kanashimini Karya Nakahara Chuya.

\section{Hasil dan Pembahasan}

Anilisis semiotik puisi 污れつちまつた悲しみに 'Kesedihan yang kotor ini"dilakukan terhadap tiga hal yaitu: (1) analisis pembacaaan heuristik dan hermeneutik, (2) analisis ketidaklangsungan ekspresi, dan (3) analisis Matrik, model, dan varian. Secara lebih detil, analisis tersebut dapat dilihat dibawah ini.

\section{1) Pembacaan heuristik dan hermeneutik}

Berikut ini adalah keseluruhan teks puisi 污れつちまつた悲しみに 'Dalam kesedihan yang kotor ini' karya Nagara Chuya.

污れつちまつた悲しみに

Yogorecchimatta kanashimini

污れつちまつた悲しみに

Yogorecchimatta kanashimini

今日も小雪の降りかかる

Kyō mo koyuki no furikakaru

污れつちまつた悲しみに

Yogorecchimatta kanashimini

今日も風さへ吹きすぎる

Kyō mo kaze-sa e fuki sugiru

污れつちまつた悲しみに Dalam kesedihan yang kotor ini

Yogorecchimatta kanashimini

たとへば狐のかわごろも

Tatoeba kitsune no ka wa goro mo

污れつちまつた悲しみに

Yogorecchimatta kanashimini

\section{Dalam kesedihan yang kotor ini}

Dalam kesedihan yang kotor ini

Turun salju lagi hari ini

Dalam kesedihan yang kotor ini

Angin berhembus kencang hari ini

Tak lain adalah jubah bulu rubah

Dalam kesedihan yang kotor ini 
小雪のかかつてちぢこまる

Menyusut dari guyuran butiran salju

Koyuki no ka katsute chidjikomaru

污れつちまつた悲しみに Dalam kesedihan yang kotor ini

Yogorecchimatta kanashimini

なにののぞむ (望む) なくねがふなくＴanpa harapan, tanpa hasrat

Nani no nozomu naku nega fu naku

污れつちまつた悲しみに

Dalam kesedihan yang kotor ini

Yogorecchimatta kanashimini

けだいのうちに死を夢む

Ke dai no uchi ni shi o yume mu

Hanya ada impian kematian yang

melelahkan

污れつちまつた悲しみに

Dalam kesedihan yang kotor ini

Yogorecchimatta kanashimini

いたいたしくも怖気づき

Dihantui ketakutan..

Itaitashikumo ojikezuki

污れつちまつた悲しみに

Yogorecchimatta kanashimini

なすところもなく日は暮れる....

Nasu tokoro mo naku hi wa kureru

Dalam kesedihan yang kotor ini

Tak berdaya hingga mentari tenggelam

Bait pertama puisi Dalam Kesedihan yang kotor ini menggambarkan suatu kondisi penyair yang sangat memprihatinkan. Penyair dilanda kesedihan yang teramat sangat. Dalam bait pertama dengan jelas dinyatakan kondisi penyair yang menyedihkan. Kondisi tersebut kembali ditekankan dengan kata 污れつ yang bermakna kotor. Kata 污れつ sendiri mengimplikasikan suatu keadaan yang menjijikkan dan sesuatu yang tidak disukai penyair. Dengan digabungnya kata 悲し yang berarti sedih dan kata 污れつ yang berarti kotor menunjukkan suatu kondisi kesdihan yang sangat menjijikkan. Dalam hal ini dapat dikatakan bahwa baris pertama 污れつちまつた悲しみに menggambarkan kondisi menyedihkan yang dirasakan penyair sangat luar biasa dan benar-benar menjijikkan. Kondisi menyedihkan penyair diperburuk lagi dengan turunnya salju pada baris kedua 今日 も小雪の降りかかる 'turun salju lagi hari ini' dan baris keempat 今日も風さへ吹きすぎ る 'angin berhembus kencang hari ini'.

Bait kedua masih bercerita perasaan sedih yang melanda penyair yang begitu mendalam. Pada bait kedua ini penyair mengibaratkan rasa sedih itu sebagai mantel bulu rubah yang selalu menyelimuti tubuhnya dari kedinginan. Kata かわご 'jubah’ dalam baris kedua bait kedua bermakna pakaian yang dikenakan pada saat musim dingin. Dalam hal ini, 
jika kata 狐のかわごろも 'jubah bulu rubah' digabungkan dengan baris 污れつちまつ た悲しみは 'Kesedihan yang kotor ini' dengan jelas menggambarkan suasana atau kondisi kejiwaan penyair yang merasa bahwa kesedihannya merupakan pakaian yang akan selalu dikenakannya saat cuaca dingin. Hal ini mengimplikasikan bahwa rasa sedih itu akan selalu ada untuk menyelimuti tubuhnya. Lebih jauh lagi, dalam kondisi dilanda kesedihan yang begitu mendalam, penyair merasa dirinya semakin mengecil dan tenggelam dalam dunia yang dingin diguyur hujan salju seperti tertuang dalam baris 小雪のかかつてちぢこまる 'Menyusut dari guyuran butiran salju'. Kata ちぢこまる 'menyusut' menunjukkan bagaimana penyair merasa dirinya semakin mengecil dan tenggelam di dalam dunia yang dingin karena diguyur 小雪 'butiran salju'. Dengan demikian dapat disimpulkan bahwa bait kedua puisi 污れつちまつた悲しみは 'Kesedihan yang kotor ini' mengambarkan kondisi penyair yang selalu diselimuti kesedihan hingga pada akhirnya dirinya merasa semakin kecil dan tenggelam dalam dunia yang dingin.

Dalam bait ketiga, penyair menggambarkan jiwanya yang dilanda suatu keputusasaan. Hal ini ditunjukkan dalam baris ke dua bait ketiga yang menggambarkan bagaimana penyair merasakan dirinya tanpa harapan dan keinginan akan datangnya pertolongan maupun kehidupan yang lebih baik. Kata なにの yang berati kosong bergabung dengan kata のぞむ yang berarti harapan membentuk makna harapan yang kosong atau dengan kata lain tanpa harapan. Penyair merasa bahwa satu-satunya hal yang menantinya adalah datangnya kematian yang telah lama ditunggunya untuk menghilangkan semua rasa sedih yang ada. Frase 死を夢む yang berati impian kematian bergabung dengan kata けだい yang berarti lelah membentuk makna impian kematian yang melelahkan. Hal ini menggambarkan bagaimana perasaan penyair yang demikian putus asa dan tidak tahan dengan semua kesedihan dalam dirinya akhirnya mengharapkan datangnya kematian sebagai jalan untuk menghilangkan rasa sedih. Sayangnya, kematian yang sudah begitu lama ditunggu penyair tidak juga datang.

Bait terakhir puisi 污れつちまつた悲しみに “Kesedihan yang kotor ini” menggambarkan kondisi kesedihan membawanya lebih jauh ke dalam rasa ketakutan seperti terungkap dalam baris いたいたしくも怖気づき 'Dihantui ketakutan..'. Apabila 
hanya melihat pada baris ini, tentu tidak dapat dipahami ketakutan apa yang sebenarnya menghantui diri penyair. Untuk mengetahui ketakutan dari penyair harus dilihat pada baris sebelumnya yaitu けだいのうちに死を夢む 'Hanya ada impian kematian yang melelahkan'. Dengan merujuk pada baris tersebut maka dengan jelas dapat diketahui bahwa rasa takut yang menghantui penyair tidak lain adalah impian kematian yang tidak kunjung datang. Hal ini mengimplikasikan bahwa penyair takut dirinya tidak dapat lepas dari kesedihan karena satu-satunya jalan untuk menghilangkan kesedihannya yaitu kematian tidak juga datang. Baris selanjutnya, yaitu なすところもなく日は暮れる...... ‘Tak berdaya hingga mentari tenggelam' menggambarkan kondisi penyair yang tak berdaya hingga hari berganti sore.

Pembacaan puisi secara hermenetik menghasilkan pemahaman bahwa puisi 污れつ ちまつた悲しみは 'Kesedihan yang kotor' bercerita kondisi kejiwaan penyair yang sedang dilanda kesedihan yang begitu mendalam. Begitu sedihnya diri penyair, sampai-sampai dia merasa keberadaan jati dirinya nyaris hilang. Rasa sedih juga membuat penyaris merasakan suatu keputusasaan, bahkan mengharapkan datangnya kematian sebagai jalan untuk menghapus kesedihannya. Di antara rasa sedih yang melanda dirinya itu, penyair selalu dihantui ketakutan akan tidak hadirnya kematian yang mampu menghapis rasa sedihnya. Pada akhirnya, penyair merasa tak berdaya dan hanya bisa merasakan kesedihan itu dari hari ke hari.

\title{
2) Ketidaklangsungan Expresi
}

\section{Penggantian arti}

Penggantian arti dalam puisi 污れつちまつた悲しみは Kesedihan yang kotor ini dapat dilihat dalam kutipan bait kedua sebagai berikut:

\author{
污れつちまつた悲しみは \\ Yogorecchimatta kanashimini \\ Kesedihan yang kotor ini \\ たとへば狐のかわごろも \\ Tatoeba kitsune no ka wa goro mo \\ Tak lain adalah jubah bulu rubah
}


Dalam kutipan bait puisi di atas, penyair menggunakan perumpamaan metafora. Dalam hal ini ungkapan 污れつちまつた悲しみは Kesedihan yang kotor ini diumpamakan sebagai 狐 のかわごろも jubah bulu rubah yang akan selalu dipakainya selama kondisi musim dingin. Perasaan penyair yang selalu diselimuti dan dibungkus oleh kesedihan membuatnya merasa bahwa kesedihan itulah yang menjadi jubah yang akan selalu dipakainya. Terdapat suatu persamaan antara kondisi sedih yang dirasakan penyair dengan jubah bulu rubah. Jubah bulu rubah merupakan sejenis pakaian yang biasanya dikenakan pada saat musim dingin untuk mencegah hawa dingin masuk ke tubuh. Dengan mengenakan mantel bulu rubah yang membungkus tubuh maka tubuh akan terasa hangat. Persamaan sifat muncul dalam fungsi jubah bulu rubah yang membungkus atau menyelimuti tubuh untuk menghangatkan badan dan kesedihan yang selalu menyelimuti jiwa penyair. Dengan demikian, membungkus atau menyelimuti menjadi titik kemiripan antara kesedihan penyair dan mantel bulu rubah.

\section{Penyimpangan arti}

Penyimpangan arti muncul dari ambiguitas kata yang digunakan dalam puisi. Pada puisi 污れつちまつた悲しみは Kesedihan yang kotor ini, ambiguitas muncul pada judul puisi itu sendiri. Kata 污れ yang bermakna kotor jelas tidak dapat diterapkan terhadap kata 悲し yang bermakna sedih. Kata 污れ 'kotor' merupakan adjektiva yang hanya biasanya disandingkan dengan nomina yang berupa benda konkrit seperti dalam kata baju yang kotor. Kata 悲し 'kesedihan' merupakan nomina yang berupa benda abstrak dari adjektiva sedih yang merujuk pada suatu keadaan jiwa manusia. Oleh karena itu, kata 污れ 'kotor' tidak cocok disandingkan dengan kata 悲し 'kesedihan'. Disandingkannya kata 污れ 'kotor' dan 悲し 'kesedihan' dalam baris 污れつちまつた悲しみは 'Dalam kesedihan yang kotor ini' berfungsi untuk menambah rasa dan nuansa kondisi kejiwaan penyair yang luar biasa sedih. Selain itu, makna kata 污れ 'kotor' menunjukkan suatu keadaan yang menjijikkan dan tidak disukai mengimplikasikan keadaan jiwa penyair yang tidak menyukai kesedihan yang melanda dirinya .

Ambiguitas juga terdapat dalam bait kedua baris keempat sebagai berikut: 
小雪のかかつてちぢこまる

Koyuki no ka katsute chidjikomaru

Menyusut dalam guyuran butiran salju

Kata ちぢこまる yang bermakna menyusut atau mengecil dalam baris 小雪のかか つてちぢこまる 'Menyusut dalam guyuran butiran salju' mengindikasikan suatu perubahan dari suatu besar menjadi kecil. Dalam hal ini, kata ちぢこまる 'menyusut' diterapakan pada suatu benda yang bisa berubah dari yang berjumlah atau berukuran besar menjadi berjumlah atau berukuran kecil. Terjadi suatu ambiguitas ketika kata ちぢこまる 'menyusut' disandingkan dengan fisik manusia seperti dalam baris 小雪のかかつてちぢこまる 'Menyusut dalam guyuran butiran salju'. Sangatlah tidak logis jika memaknai kalimat tersebut secara literal. Tubuh fisik penyair tidak mungkin menyusut secara drastis apalagi kalau sampai seukuran butiran salju. Oleh karena itu, dapat dikatakan bahwa kata ちぢこま る 'menyusut' dalam kalimat 小雪のかかつてちぢこまる 'Menyusut dalam guyuran butiran salju' mempunyai makna lain yang ingin disampaikan oleh penyair. Apa yang menyusut dalam kalimat 小雪のかかつてちぢこまる'Menyusut dalam guyuran butiran salju' bukanlah tubuh fisik penyair tetapi lebih kepada jatidiri ataupun keberadaan diri sang penyair karena dirundung kesedihan yang sangat mendalam. Penyair merasa jati dirnya nyaris tidak ada bahkan mungkin akan hilang dan tenggelam di dalam guyuran butiran salju.

Ambiguitas lain juga ditemukan dalam bait keempat baris keempat sebagai berikut:

なすところもなく日は暮れる…

Nasu tokoro mo naku hi wa kureru

Tak berdaya hingga mentari tenggelam

Pada baris なすところもなく日は暮れる.... ‘Tak berdaya hingga mentari tenggelam' ambiguitas muncul dalam ungkapam 日は暮れる 'mentari tenggelam'. Ungkapan 日は暮れる 'mentari tenggelam' secara literal berarti waktu ketika matahari tenggelam atau sore hari. Dengan demikian secara literal baris なすところもなく日は暮れ る.... 'Tak berdaya hingga mentari tenggelam' bermakna kondisi penyair yang tak berdaya hingga sore hari. Ungkapan 日は暮れる 'mentari tenggelam' juga dapat dimaknai sebagai pergantian waktu. Waktu saat matahari tenggelam atau sore hari hari merupakan saat 
dimana terjadi pergantian siang hari menuju malam hari. Dalam hal ini, ungkapan 日は暮れ る 'mentari tenggelam' mengimplikasikan makna pergantian waktu baik dari siang hari menuju malam hari atau secara lebih luas dari satu hari ke hari berikutnya. Apabila makna pergantian waktu yang digunakan, maka ungkapan なすところもなく日は暮れる.... 'Tak berdaya hingga mentari tenggelam' mengandung makna bahwa penyair merasa tak berdaya terus menerus dari satu hari ke hari berikutnya.

\section{Penciptaan arti}

Penciptaan arti yang ada dalam puisi 污れつちまつた悲しみは‘Kesedihan yang kotor ini' terdapat dalam simitri baik yang berupa penyamaan bunyi akhir maupun pada pengulangan baris dalam puisi. Bentuk pengulangan ritme tersebut dapat dilihat dalam contoh bait pertama berikut ini.

\section{污れつちまつた悲しみに Yogorecchimatta kanashimini 今日も小雪の降りかかる Kyō mo koyuki no furikakaru 污れつちまつた悲しみに Yogorecchimatta kanashimini 今日も風さへ吹きすぎる Kyō mo kaze-sa e fuki sugiru}

Kutipan puisi bait pertama di atas menggunakan ritme yang berbentuk asonansi yaitu pengulangan pada bunyi vokal dan jenis ritme silang dengan pola sajak $a-b-a-b$. Baris pertama dan ketiga diakhiri dengan bunyi ni dan pada baris ke dua dan keempat diakhiri bunyi $r u$. Penggunaan asonansi dalam bait di atas menimbulkan nuansa puitis yang kuat terhadap apa yang ingin disampaikan penyair.

Bentuk penciptaan arti lain dalam ritme puisi 污れつちまつた悲しみは 'Kesedihan yang kotor ini' dapat dilihat dalam pengulangan baris 污れつちまつた悲しみは 'Kesedihan yang kotor ini'. Dari 16 baris yang membentuk puisi, ungkapan 污れつちまつた悲しみは 'Kesedihan yang kotor ini'muncul sebanyak 16 kali yaitu pada baris pertama dan ketiga dalam setiap bait. Dengan pengulangan baris yang berkali-kali, memunculkan kesan bahwa penyair memberikan perhatian khusus atau fokus terhadap ungkapan 污れつちまつた悲し 
みは 'Kesedihan yang kotor ini'. Dalam hal ini, ungkapan tersebut menjadi bagian utama yang ingin diungkapkan penyair melalui puisi.

\section{3) Matrik, Model dan Varian}

Pada puisi 污れつちまつた悲しみは yang menjadi matrik puisi adalah perasaan sedih yang mendalam yang melandai hati penyair. Model dalam puisi adalah kesedihan yang kotor, sedangkan varian dalam puisi dapat dijabarkan sebagai berikut:

1. Kesedihan yang kotor selalu menyelimuti penyair dan membawanya tenggelam dalam kedinginan dunia guyuran salju sebagaimana terungkap pada bait kedua

2. Kesedihan yang kotor menimbulkan rasa putus asa dalam diri penyair hingga merasa tak ada harapan dan keinginan bahkan penyair menanti datangnya kematian sebagai satu-satunya jalan untuk menghilangkan rasa sedihnya. Hal ini terungkap pada bait ke tiga baris kedua dan keempat.

Kesedihan yang kotor memunculkan rasa takut yang selalu menghantui penyair. Rasa takut jika kematian tidak menjemputnya hingga pada akhirnya penyair tak berdaya dan hanya bisa menjalani rasa sedihnya dari hari ke hari seperti terungkap dalam bait keempat baris kedua dan keempat

\section{Simpulan}

Berdasarkan hasil analisis terhadap puisi 污れつちまつた悲しみは 'Kesedihan yang kotor ini' dapat ditarik simpulan bahwa hasil pembacaan heuristik dan hermeneutik puisi menunjukkan puisi itu menggambarkan kondisi jiwa penyair yang sedang dilanda kesedihan yang sangat mendalam. Kesedihannya itu membuat diri penyair merasa kehilangan jati diri, putus asa sampai mengharapkan datangnya kematian, serta tak berdaya. Ketidaklangsungan ekspresi ditunjukkan melalui pengantian arti yang berupa penggunaan metafora, penyimpangan arti yang terjadi karena ambiguitas, serta penciptaan arti melalui asonansi dan pengulangan baris. Analisis matrik, model, dan varian menunjukkan bahwa perasaan sedih yang mendalam menjadi matrik puisi, kesedihan yang kotor menjadi model puisi, serta terdapat tiga varian yaitu kesedihan membuat penyair tenggeam dalam guyuran butiran salju, kesedihan membuat penyair putus asa, dan kesedihan membuat penyair tak berdaya. 


\section{Daftar Pustaka}

Pradopo, Rachmat Djoko. (1997). Prinsip-prinsip Kritik Sastra. Yogyakarta: Gadjah Mada University Press

(2010). Pengkajian Puisi. Yogyakarta: Gadjah Mada University Press.

Prahasita, Naratungga Indit. (2016). Semiotika Riffaterre untuk Elegy Laut Sofyan Daud. Gramatika. Volume IV, Nomor 2, Juli-Desember 2016. hlm. 125-132

Ratih, Rina. (2016). Teori dan Aplikasi Semiotik Michael Riffaterre. Yogyakarta: Pustaka Pelajar.

Riffaterre, Michael. (1978). Semiotics of Poetry. London: Indiana of University Press

Sayuti, Suminto A.(2002). Berkenalan dengan Puisi. Yogyakarta: Gama Media.

Sobur, Alex. (2004) . Semiotika komunikasi. Bandung: Remaja Rosdakarya

https://ebitoro.wordpress.com/2018/03/01/this-soiled-sorrow [ 污れつちまつた悲しみ は]translation. 